\title{
The Scope of the Concept of Information and the Future of Information Science
}

\author{
Jiř́i T. Stodola \\ Division of Library and Information Studies \\ Department of Czech Literature and Library Studies \\ Faculty of Arts \\ Masaryk University, Brno, Czech Republic
}

stodola5@gmail.com

\begin{abstract}
The key concept of information science is the concept of information which is tied to a number of complications. The main problem is that there is no definition of this concept. The purpose of this article is an analysis of the concept of information from the position of classical logic. The main method of the article is a conceptual analysis. First, we briefly deal with the overview of the concepts of information, with concepts and their definition as such and with the scope of the concept of information. Then, we provide an analysis of 31 important definitions of the concept of information which were developed within the scope of information science and related fields, and we consider relations between the concept of information and the concepts in other disciplines. Conceptual analysis of the concept of information leads to the conclusion that information is probably a concept that somehow addresses the entire reality, thus that it is a term, which is in the classical logic described as transcendental. This fact, in the view of the fact that information science is a special field, seems to be a serious methodological problem. Problems associated with the broadness of the concept of information have three possible solutions: transformation of information science into the universal science, narrowing the concept of information to a special term, or replacement of the concept of information by a different one. At the end of the article, we briefly point out our solution to the problem.
\end{abstract}

Keywords: concept of information, scope of the concept, information science, definitions, conceptual analysis

\section{Introduction}

There are many definitions of the term information, without any of them being accepted in general, and each definition, the number of which continues to grow, fundamentally differ from one another [36, p. 27]. This situation can be described as a paradox, considering the fact that information is often understood as a reduction of uncertainty [11, p. 351].

Because of this problem, some authors stop asking what the information is, but rather ask what kind of concept is it, that it is accompanied by such difficulties [14]. 
It seems, therefore, that it is necessary to proceed to a more radical revision of this term. Such a revision, however, cannot be done without a thorough epistemological and logical analysis of the concept of information.

The aim of this article therefore isn't to extend the range of definitions of information, but rather to contribute to the epistemological and logical debate over the nature of this term.

The paper will attempt to respond to two central questions, namely

- What sort of concept does information represent in view of scope?

- How does such classification affect information science as a discipline?

In order to find appropriate responses, we need to clarify the following problems:

- What do concepts mean for the related scholarly or scientific theory?

- What criteria can be used to classify concepts and to analyze the concept of information?

Responding to these fundamental issues constitutes the input methodological basis of the paper.

First, we briefly deal with the concept of information in various domains, with literature considering the substance of the concept of information and its definitions, with the concept as such and with the scope of the concept of information. Then we provide the analysis of several important definitions of the concept of information, which were created within information science and related fields. From the collected data, some conclusions about the nature of the concept of information are deduced and an attempt is made to outline its future destiny in information science. The basic method consists in the conceptual analysis of definitions.

\section{A brief overview of the concept of information}

Information is a concept that is very used nowadays, namely in many areas [71]. It is not surprising that the experts struggle with its definition, and that its definitions are often quite different from each other. It is often shown in various knowledge contests, that it is difficult to explain particularly those words with which we meet today and every day. This is because these words become commonplace for us so much that we no longer even think about what they mean. At the same time, to know the meaning of the words that we use is absolutely necessary and it is the first step to eliminate many misunderstandings.

The concept of information is mainly connected with the Aristotelian and Scholastic philosophy [13]. According to this philosophical direction, the essence of each material existence is composed of two metaphysical parts - form and materia. The substance (materia) is a passive principle which is able to receive the shapes. The form (shape) is an active principle which makes the thing what it is; it defines the substance or informs. 
The concept of information has been revived with the advent of cybernetics [70], a science on control and communication in the systems. In the cybernetic concept, the information is a degree of the removal of uncertainty in the system, the degree of its orderliness. The analogy with the previous concept is obvious - but it is a mathematical theory.

From the cybernetics, which is considered a theory permeating all scientific disciplines, the concept of information is spreading into many other disciplines. For example, cognitive psychology and science adopt it, and they understand the information as a psycho-physiological phenomenon and process under way in human consciousness. Information determined (informs) the knowing subject.

With the arrival of the first universal machine - computer - a field arises which has the concept of information in its name, in Czech - informatics. Within the concept of this field, the information is data circulating in computers.

Recently, it has also been a revival of this concept in the field of philosophy. Brno philosopher Josef Šmajs [66] sees the information as a constitutive factor of evolution. His philosophical reflection of information is based on cybernetic and genetic concept, however as it is a philosophical concept, it continues also (probably partly unconsciously) in the hylemorfic traditional approach.

Last but not least, the concept of information also reaches into everyday language, which contributes to its unclarity. On the words that are used commonly, different meanings are gradually applied, which makes them seem understandable, but an attempt on their exact definition, however, usually ends in failure.

The concept of information plays the key role in information science. There have been several paradigmatic turns [22] within the field, which have brought a new light into this term. During the first of them, the peripheral concept of information became a basic term, which replaced the former concept of document (because of this, the documentation has changed into information science) [13, p. 379]. In the context of the first turn, the information is perceived as something related to the information system, that means to the system, which is used for retrieving, sorting, storage, searching and dissemination of information (examples of such systems may be a library or an electronic database). The second turn, the so called cognitive turn, meant a deflection from the information system and shift of the focus to the user of information. Within its scope, the concept of information began to be considered in relation to the mental representation of the world, which creates a cognitive subject [7]. The third turn, social, focused its attention on the information creator and it began to describe the information as a social construct [38].

\section{Overview of literature dealing with the definition and nature of the concept of information}

The definition of the concept of information differs between paradigms, but also within a single paradigm. That is why - as has been said above - attempts are being made to raise questions about the very possibility of providing a definition of concepts and the nature of the concept of information rather than merely to add another definition. 
Capurro and Hjørland [13] refer to Wittgenstein's claim that rather than attempting a classical definition using the proximate genus and a specific difference, it is better to look at how people use the terms. Etymological investigations of the given term are also important. Both authors consider each definition relative to the theory in whose framework it is created; one could say that a universal definition cannot be created - only a definition that works within a certain theoretical framework. They also deal with the concept of information as an interdisciplinary context, exploring the concept of information in the natural and social sciences and the humanities, and also in information science. They emphasize the differentiation of information as an object or thing and information as a subjective notion or sign that requires interpretation.

Case [18] explores the concept of information using the concept of explication a systematic attempt to determine the meaning of concepts. Explication, at the start of which we have only a general understanding of the meaning of the word, begins with examining the etymology of the term and continues through dictionary definitions to the definitions given by individual authors in the field. Thus, it is found that different authors define the given term differently, but also that some authors speak of the given term, but under a different name. Explication is achieved by extracting a common core from different definitions (top-down method) or by finding out what is common to subordinate concepts (bottom-up method). Case further deals with individual definitions of information and their problems, such as utility, physicality, structure/process, intentionality, truth. In conclusion, he asks whether we need a universal definition of the concept of information and whether information is not possibly a primitive concept that does not need to be defined but that is intuitively comprehensible.

Day [23] deals with the concept of information from the perspective of the critical theory. He does not ask what information is, or whether it is good or bad, but he is interested in the connotations of this term. He demonstrates that authoritative texts on the concept of information use language to construct the social, utopian value of information as something factual and given that promotes privileged, totalitarian discourse. Similarly, Bernd Frohmann [32] stays away from the question of what information is - he considers it a superfluous concept. He shows that the concept of document is much more useful. Jonathan Furner [34] also considers the concept of information to be redundant, arguing that the notion of information is fully replaceable with concepts of philosophy of language.

Our goal is to reflect on the concept of information and its influence on information science from the position of a classical theory of concepts and theory of definition and to explore what these assumptions, which most modern authors consider to be overcome, can bring us.

\section{Concept of concepts}

Concepts embody the foundation stones of every scholarly or scientific discipline. A particular field of science is markedly pre-determined by its own object; that is, its character emulates the properties of the investigated problem. Thus, a discipline arises 
from the conceptual definition of the object to be examined, proceeding towards the subsequent derivation and classification of other concepts.

Within logic and other disciplines, there are many approaches to concepts. Kavouras and Kokla [43] distinguish five basic theories of concepts (classical, probabilistic, theory-based, neoclassical, and conceptual atomism).

Birger Hjørland [39] divides the approaches to concepts by epistemological schools (empiricism, rationalism, historicism, pragmatism), within which the concepts is discussed. W. G. Stock [63] assumes the Hjørland's division (with the difference of calling the historicism a hermeneutics and adding the critical theory) and he displays it using the following scheme:

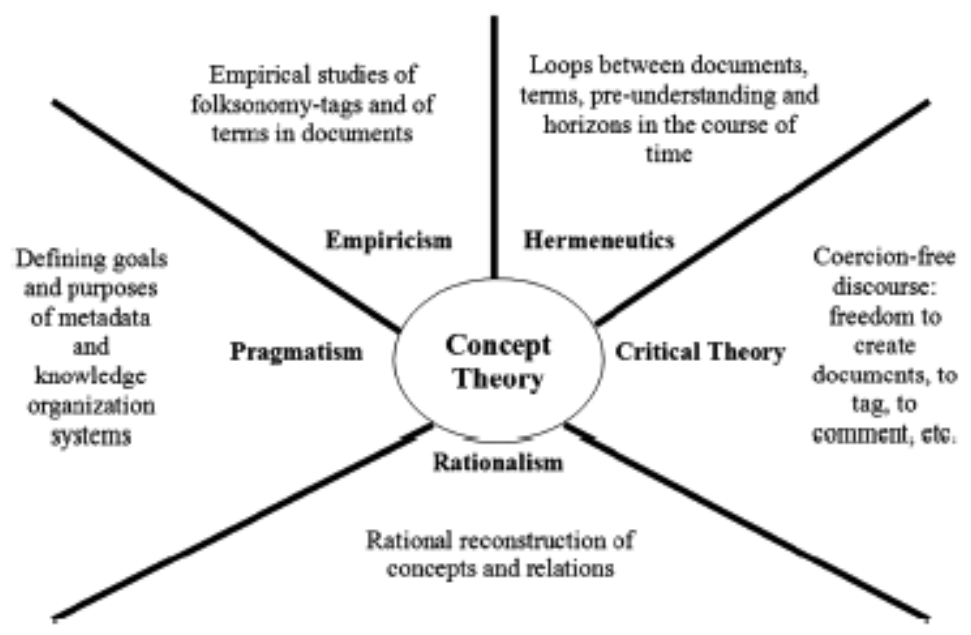

Figure 1. Theory of concepts and the epistemology schools [63, p. 1953]

We assume that the scientists who are trying to define and use certain concept, usually do not come out explicitly from a particular epistemological direction (in most texts defining the concept of information, the epistemological statement of the nature of concepts is missing) (for example [3]). It is clear that every effort to define scientific concepts must be based on certain epistemological assumptions; however, it is common, that these assumptions are only implied and the experts understand them rather intuitively, even if they try to change their angle of view on the given term. The works which analyze the epistemological bases, usually have no ambitions to define the concepts (for example [13]).

We dare to say that the intuitive understanding of the terms, which is present in most of the works dealing with their definition, is closest to what Kavouras and Kokla [43] call the classical theory [see also 61]. How does such intuitive conception of concepts usually look like? Scientists usually consider concepts as a tool, which is used to recognize the reality and which is not identical with that reality (the concept means to them a representation of the reality in knowledge). They also recognize that the concept is abstract, therefore, that the concept does not cover all aspects of reality, 
but only those that are essential and not dependent of specific material conditions. They usually think, that the concept is general (not everyone, but at least the one that is considered to be scientific), so that one concept describes a certain property that occurs in reality many times in different contexts. It is usually clear to them, that there is a difference between the concept and the word which labels the concept (it is evidenced by the simple fact that the same concept is described in different languages using different words). They also believe that the concept has a content, that is created by just that aspect of reality, expressed by that concept, and the extent which covers all objects, properties and relationships to which the aspect can be assigned.

We can therefore assume, that the majority of scientists working with concepts, at least implicitly accept the definition of the concept, which can be formulated as follows: The concept is an abstract (and usually general) actualization of a part of the reality in knowledge that is for the purpose of human communication expressed through linguistic expressions (compare with [54, p. 38]). This classic concept of concepts can be illustrated on the reference triangle, which W.G. Stock [63, p. 1952] presents in this form:

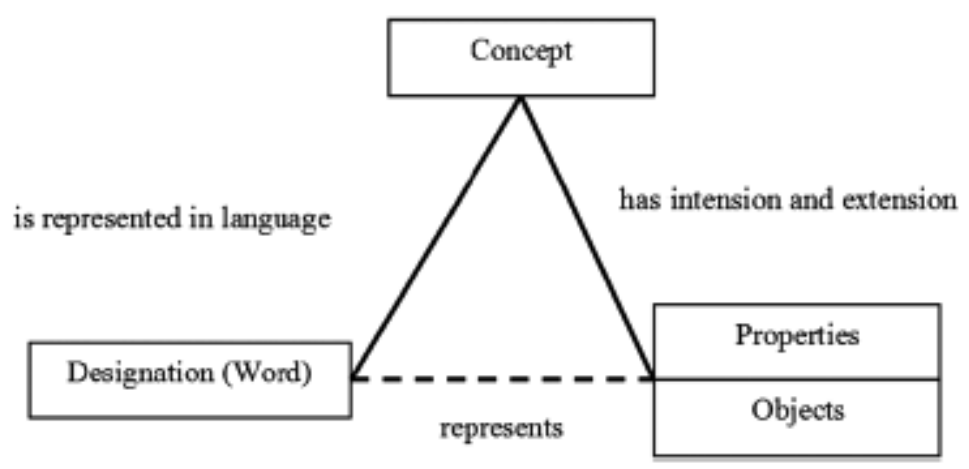

Figure 2. The reference triangle

\section{Scope of the concept}

Concepts can be classified using different criteria in many ways. One of them is the aspect of the content (it concerns one of the content aspects, not the content aspect as such), according to which the concepts are divided into univocal, analogical and equivocal [54, pp. 74-79]. In information science, these questions focused on the concept of information are known as the Capurro's trilemma [14]. For several reasons, we consider this trilemma in information science unsolvable. (Strictly speaking, these issues cannot be solved within the framework of information science simply because they are ontological and epistemological issues that can be solved only in philosophy. But that is not the problem, because the special discipline always accepts, at least implicitly, some philosophical basis. Problem of these issues rests in the fact that they stand outside the scope of interest of the recent philosophy and therefore they become 
incomprehensible even for philosophically oriented information scientist.) These reasons include especially:

- these questions require relatively subtle metaphysical analysis, which is not only incomprehensible to the information scientist, but even to the majority of contemporary philosophers (only a handful of classically oriented researchers deal with them) (for example [61]);

- various philosophical schools offer different solutions that are well reasoned, and it is not within the competence of the information scientists to evaluate them and decide for one of them (compare with [54, pp. 72-79]).

As much more feasible, we consider exploring the concepts, and the concept of information separately, in terms of aspect of the scope, which says the number of objects in reality to which the concept is assigned (i.e. number of objects the concept has within its scope). According to this criterion, we recognize individual, general and transcendental concepts [54, p. 66]. The individual concept has in its scope only one object, the general concept is assigned to two or more objects, and the transcendental concept belongs to all that exists or can exist. An example of the individual concept may be a concept of a particular human, which we describe by his name (Socrates). The general concepts are all the species concepts (dog, horse, human), and generic concepts (animal, plant). Transcendental notions contact reality as a whole (something, being, and so on) [16].

The nature of special science implies that the general concepts are in the center of its interest [55, p. 28]. Through the individual concept is not possible to cover general issues of the reality, the transcendental concepts cannot be part of a special science for its thematic narrowness [1, p. 35] that is because the special science is interested only in a certain part of the reality, which is being framed by concepts (the transcendental concepts include the entire reality, and therefore they are the domain of metaphysics, which deals with being as being) [17]

Our dilemma is: Is the concept of information general or transcendental? Let's think about it, before we analyze the definitions of the concept of information. Kenneth E. Boulding [9] talks about three basic models of the world, which fundamentally affected the scientific methodology. The first model is static, associated with the medieval view of the world, the second one is dynamic, which came to life with the development of Newtonian physics, and the third one is based on the principle of a feedback, in which the information plays a critical role. Ilya Prigogine and Isabelle Stengers [57] also distinguish three phases of science. They associate the first one with a focus on mass, the second one with energy research and the third one with the discovery of information.

According to these authors, the concept of information is not a concept that is used exclusively in a particular discipline, but it is a multidisciplinary term, which has its application in most of the natural and social sciences and even in the science that has a universal scope - in philosophy (see for example [28]). Philosophy covers the whole area of reality and the concept of information is not too narrow for it; special sciences divide among themselves the entire reality and yet the concept of information 
plays an important role in almost every one of them. Philosophical reasoning leads to the fact, that the concept of information is considered to be transcendental. In the analytical part, we try to check whether this is really so.

\section{Definition of information}

The basic method of defining the concept is the definition. The definition is a mind product expressed by words, through which it is explained what is the defined object, represented by the concept (what is its essence) (compare with [51).

The traditional approach to the definition, which is intuitive and is therefore usually implicitly accepted by all the authors who attempt to provide definitions of basic scientific terms, the conceptual explanation usually fits best. Definitions using the concept explanation consist of a defined concept (definiendum), the content of which is equivalent to the intersection of the two partial concepts contents (definiens). Combination of the partial concepts creates the concept identical to the concept defined (=df means equivalence by the definition) [63, p. 1952]; the meaning of the defined concept is explained by using partial notions.

\section{Concept $=$ df partial concept $1 \cap$ partial concept 2}

In this section, we mention some definitions of the term "information" created within the information science and related fields. The given overview is then analyzed. Thirtyone definitions of the term "information" created by different authors were selected for analysis. In the selection, we were guided by the distinction of basic approaches to defining and classifying the term of "information" stated by Marcia J. Bates [4] and Donald O. Case [18]. To this we add some definitions of information that we encountered in our research and that we find interesting.

Bates distinguishes seven approaches:

- Communicatory or semiotic

- Activity-based (i.e., information as event)

- Propositional

- Structural

- Social

- Multi-type

- Deconstructionist

The communicatory and semiotic concept can include the definitions of Bateson, Lossee, Madden, Nauta; A. D. Madden defines the information as "stimulus which expands or amends the World View of the informed" [48, p. 9]. G. Bateson says that information is "difference that makes difference" [5, p. 453]. According to D. Nauta, the information is "that which is common to all representations that are synonymous to the interpreter (synonymity is identity of meaning)" [53, p. 201]. R. Losee defines the information as "values in the characteristics of the processes' output" [45, p. 256]. An approach based on the activity is represented by A. Pratt, who says that the 
information is "alternation of the Image which occurs when it receives a message" [56, p. 215].

Propositional definition of the information is given by R. Derr and F. Dretske. R. Derr defines the information as "abstract, meaningful representation of determinations which have been made of objects" [24, p. 491]. F. Dretske claims that the information "is capable of yielding knowledge" [25, p. 45].

Frederick Thomson provides the structural definition, which states that the information is "that result from applying the processes of organization to the raw material of experience, much like steel is obtained from iron ore". [67, p. 305]

Cornelius and Goguen represent the social definitions. Cornelius says that the information is "human artefact constructed and reconstructed within social situations" $[21$, p. 19). According to Goguen information is "of a configuration of signs for which members of some social group are accountable" [36, p. 31].

Bates, Buckland and MacKay represent the multi-type approach. According to Bates the information is "pattern of organization of matter and energy" [3, p. 1033]. Buckland defines the information as "quality attributed to things" [11, p. 355]. MacKay says that the information is "which determines form" [47, p. 160].

A different classification of the definitions of information is provided by Donald O. Case [18], who notes 5 aspects related to the definition of information:

- utility,

- physicality,

- $\quad$ structure/process,

- intentionality, and

- truth.

In terms of utility, information is often defined as a reduction of uncertainty. Boauazza argues that the most useful definition of information is that information is "that which reduces uncertainty" [8, p. 145]. Wersing and Neveling state that information is "reduction of uncertainty caused by communicated data" [69, p. 138]. Rogers defines information as "patterned matter-energy that affect the probabilities of alternatives available to an individual making a decision" [59, p. 85]. For Hirshleifer the term of information is defined as "a negative measure of uncertainty" [37, p. 31].

Some authors believe that the essential condition of information is its physicality. Krippendorff places information in relation to the concept of energy and argues that information is a "measure of the (intellectual) work required to distinguish, to a degree better then chance, among a set of initially uncertain possibilities" [44, p. 50].

Information is also often defined in connection with the concepts of structure or process. Belkin and Robertson argue that information is "that which is capable of transforming structure" [6, p. 198]. Fox criticizes the concept of information as a process that changes the structure and posits that information from an ontological point of view are "propositions [the identification of which] depends on contextual factors" [30, p. 213].

Many authors associate information with intentionality, that is, the intention of the author or the recipient to communicate. Information as part of communication 
must be intentional. Primarily, however, it is a property of communication, so there is no definition of information that explicitly states intentionality.

Truth is often presented as a condition of information. According to Luciano Floridi, information is "well-formed, meaningful and truthful data" [28]. Budd argues that information consists of "meaningful, communicative actions that aim at truth claims and conditions." [12, p. 56].

Now let us focus on the selection of interesting definitions itself. We can divide them into three groups. The first group contains authors who understand information as something objective and do not consider the human subject. The second group includes authors for whom the human subject is an inherent part of the information process; the information is mainly on the part of the subject. The third group consists of authors who, while they do not deny the role of a human subject, nevertheless see information on the part of a record of human knowledge through a sign system, either identifying it directly with this record or with its meaning.

First, Gackowski attempts to exclude subjectivity from the definition of information, which he perceives as a "factor in form ... not yet available" [35, p. 172]. An objectivist and structural conception of information is offered by Luhn, who claims that information is "a structure-(form-)enriching message (which gets received by a system) in conjunction with the causal structure-(form-)giving overall process (all systems and messages)" [46, p. 154]. A similar view is held by Stonier, who understands information as a "capacity to organize a system - or to maintain it in an organised state" [65, p. 26].

Second, the founder of cybernetics, Wiener understands information as a process that takes place between a human and the world and defines it as "content of what is exchanged with the outer world as we adjust to it, and make our adjustment felt upon it" [70, p. 16]. According to Faithorne, information is an "attribute of the receiver's knowledge and interpretation of the signal, not of the sender's, nor some omniscient observer's nor of the signal itself' [26, p. 255].

In Resnikoff's view, information comes into existence by abstracting from material conditions. Hence, a subject that performs the abstraction is taken into consideration. Resnikoff argues that information is "what remains after one abstracts from the material aspects of physical reality" [58, p. 2].

Third, Bar-Hillel elaborates directly on Shannon's theory of information and incorporates a semantic dimension. In his concept, information is "what is expressed by the signal sequence" [2, p. 94]. Farradane considers information as a material object and claims that information is a "physical surrogate of knowledge" [27, p. 17]. Similarly, Meadows defines information as "data processed and assembled into a meaningful form" [52, p. 105].

For clarity, we present the individual definitions in the table:

\begin{tabular}{|c|c|c|c|c|c|}
\hline Author & Species & $=$ & $\begin{array}{c}\text { Proximate } \\
\text { genus }\end{array}$ & $\cap$ & Specific difference \\
\hline $\begin{array}{c}\text { Bar-Hillel [2, } \\
\text { p. 94] }\end{array}$ & Information & $=$ & what & $\cap$ & $\begin{array}{c}\text { is expressed by the signal } \\
\text { sequence }\end{array}$ \\
\hline
\end{tabular}




\begin{tabular}{|c|c|c|c|c|c|}
\hline Author & Species & $=$ & $\begin{array}{l}\text { Proximate } \\
\text { genus }\end{array}$ & $\cap$ & Specific difference \\
\hline $\begin{array}{c}\text { Bates [4, p. } \\
1033]\end{array}$ & & & pattern & & $\begin{array}{c}\text { of organization of matter } \\
\text { and energy }\end{array}$ \\
\hline $\begin{array}{l}\text { Bateson [5, } \\
\text { p. 453] }\end{array}$ & & & difference & & that makes difference \\
\hline $\begin{array}{l}\text { Belkin a } \\
\text { Robertson } \\
{[7, \text { p. 198] }}\end{array}$ & & & that & & $\begin{array}{l}\text { which is capable of } \\
\text { transforming structure }\end{array}$ \\
\hline $\begin{array}{l}\text { Boauazza [8, } \\
\text { p. } 145]\end{array}$ & & & that & & $\begin{array}{c}\text { which reduces } \\
\text { uncerntainty }\end{array}$ \\
\hline $\begin{array}{l}\text { Buckland } \\
{[11, \text { p. } 355]}\end{array}$ & & & quality & & attributed to things \\
\hline $\begin{array}{l}\text { Budd [12, p. } \\
\quad 56]\end{array}$ & & & actions & & $\begin{array}{l}\text { meaningful, } \\
\text { communicative... } \\
\text { that aims at truth claims } \\
\text { and conditions }\end{array}$ \\
\hline $\begin{array}{l}\text { Cornelius } \\
{[21, \text { p. 19] }}\end{array}$ & & & $\begin{array}{l}\text { human } \\
\text { artefact }\end{array}$ & & $\begin{array}{l}\text { constructed and } \\
\text { reconstructed within } \\
\text { social situations }\end{array}$ \\
\hline $\begin{array}{l}\text { Derr [24, p. } \\
\quad 491]\end{array}$ & & & representation & & $\begin{array}{c}\text { abstract, meaningful } \\
\ldots \text { of determinations } \\
\text { which have been made of } \\
\text { objects }\end{array}$ \\
\hline $\begin{array}{l}\text { Dretske [25, } \\
\text { p. } 45]\end{array}$ & & & what & & $\begin{array}{c}\text { is capable of yielding } \\
\text { knowledge }\end{array}$ \\
\hline $\begin{array}{l}\text { Fairthorne } \\
(1954: 255)\end{array}$ & & & attribute & & $\begin{array}{l}\text { of the receiver's } \\
\text { knowledge and } \\
\text { interpretation of the } \\
\text { signal, not of the } \\
\text { sender's, nor some } \\
\text { omniscient observer's nor } \\
\text { of the signal itself }\end{array}$ \\
\hline $\begin{array}{l}\text { Farradane } \\
{[26, \text { p. 17] }}\end{array}$ & & & $\begin{array}{l}\text { physical } \\
\text { surrogate }\end{array}$ & & of knowledge \\
\hline Floridi [28] & & & data & & $\begin{array}{l}\text { well-formed, meaningful } \\
\text { and truthful }\end{array}$ \\
\hline $\begin{array}{l}\text { Fox [30, p. } \\
213]\end{array}$ & & & propositions & & $\begin{array}{l}\text { depends on contextual } \\
\text { factors }\end{array}$ \\
\hline $\begin{array}{l}\text { Gackowski } \\
{[35, \text { p. } 172]}\end{array}$ & & & factor & & $\begin{array}{c}\text { in form ... not yet } \\
\text { available }\end{array}$ \\
\hline $\begin{array}{l}\text { Goguen [36, } \\
\text { p. 31] }\end{array}$ & & & interpretation & & $\begin{array}{c}\text { of a configuration of } \\
\text { signs for which members }\end{array}$ \\
\hline
\end{tabular}




\begin{tabular}{|c|c|c|c|c|c|}
\hline Author & Species & $=$ & $\begin{array}{c}\text { Proximate } \\
\text { genus }\end{array}$ & $\cap$ & Specific difference \\
\hline & & & & & $\begin{array}{c}\text { of some social group are } \\
\text { accountable }\end{array}$ \\
\hline $\begin{array}{l}\text { Hirshleifer } \\
{[37, \text { p. } 31]}\end{array}$ & & & measure & & $\begin{array}{c}\text { a negative... } \\
\text { of uncerntainty }\end{array}$ \\
\hline $\begin{array}{l}\text { Krippendorff } \\
{[44, \text { p. } 50]}\end{array}$ & & & measure & & $\begin{array}{l}\text { of the (intellectual) work } \\
\text { required to distinguish, to } \\
\text { a degree better then } \\
\text { chance, among a set of } \\
\text { initially uncertain } \\
\text { possibilities }\end{array}$ \\
\hline $\begin{array}{c}\text { Losee }[45, \mathrm{p} . \\
256]\end{array}$ & & & values & & $\begin{array}{l}\text { in the characteristics of } \\
\text { the processes' output }\end{array}$ \\
\hline $\begin{array}{l}\text { Luhn }[46, \mathrm{p} . \\
\quad 154]\end{array}$ & & & message & & $\begin{array}{l}\text { a structure-(form- } \\
\text { )enriching ... (which gets } \\
\text { received by a system) in } \\
\text { conjunction with the } \\
\text { causal structure-(form- } \\
\text { )giving overall process } \\
\text { (all systems and } \\
\text { messages) }\end{array}$ \\
\hline $\begin{array}{l}\text { MacKay }[47, \\
\text { p. 160] }\end{array}$ & & & that & & which determines form \\
\hline $\begin{array}{l}\text { Madden [48, } \\
\text { p. 9] }\end{array}$ & & & stimulus & & $\begin{array}{c}\text { which expands or amends } \\
\text { the World View of the } \\
\text { informed }\end{array}$ \\
\hline $\begin{array}{l}\text { Meadows } \\
{[52, \text { p. } 105]}\end{array}$ & & & data & & $\begin{array}{l}\text { processed and assembled } \\
\text { into a meaningful form }\end{array}$ \\
\hline $\begin{array}{l}\text { Nauta [53, p. } \\
\text { 201] }\end{array}$ & & & that & & $\begin{array}{l}\text { which is common to all } \\
\text { representations that are } \\
\text { synonymous to the } \\
\text { interpreter (synonymity is } \\
\text { identity of meaning) }\end{array}$ \\
\hline $\begin{array}{l}\text { Pratt [56, p. } \\
\quad 215]\end{array}$ & & & alternation & & $\begin{array}{c}\text { of the Image which } \\
\text { occurs when it receives a } \\
\text { message }\end{array}$ \\
\hline $\begin{array}{l}\text { Resnikoff } \\
{[58, \text { p. 2] }}\end{array}$ & & & what & & $\begin{array}{l}\text { remains after one } \\
\text { abstracts from the } \\
\text { material aspects of } \\
\text { physical reality }\end{array}$ \\
\hline $\begin{array}{l}\text { Rogers [59, } \\
\quad \text { p. } 85]\end{array}$ & & & matter-energy & & $\begin{array}{l}\text { patterned... } \\
\text { that affect the } \\
\text { probabilities of }\end{array}$ \\
\hline
\end{tabular}




\begin{tabular}{|c|c|c|c|c|c|}
\hline Author & Species & $=$ & $\begin{array}{c}\text { Proximate } \\
\text { genus }\end{array}$ & $\cap$ & Specific difference \\
\hline & & & & & $\begin{array}{c}\text { alternatives available to } \\
\text { an individual making a } \\
\text { decision }\end{array}$ \\
\hline $\begin{array}{l}\text { Stonier }[65, \\
\text { p. 26] }\end{array}$ & & & capacity & & $\begin{array}{c}\text { to organize a system - or } \\
\text { to maintain it in an } \\
\text { organised state }\end{array}$ \\
\hline $\begin{array}{l}\text { Thompson } \\
{[67, \text { p. 305] }}\end{array}$ & & & product & & $\begin{array}{l}\text { that results from applying } \\
\text { the processes of } \\
\text { organization to the raw } \\
\text { material of experience, } \\
\text { much like steel is } \\
\text { obtained from iron ore }\end{array}$ \\
\hline $\begin{array}{l}\text { Wersing a } \\
\text { Neveling } \\
{[69, \text { p. 138] }}\end{array}$ & & & reduction & & $\begin{array}{l}\text { of uncerntainty caused by } \\
\text { communicated data }\end{array}$ \\
\hline $\begin{array}{l}\text { Wiener }[70, \\
\text { p. 16] }\end{array}$ & & & content & & $\begin{array}{l}\text { of what is exchanged with } \\
\text { the outer world as we } \\
\text { adjust to it, and make our } \\
\text { adjustment felt upon it }\end{array}$ \\
\hline
\end{tabular}

Table 1. Definitions of information

\section{Conceptual Analysis}

The method used is conceptual analysis. When pursuing the given objectives, we combined into more general categories the concepts present in the place of the defined object within individual definitions, thus obtaining 6 categories. These are as follows:

- $\quad$ structure, orderliness, organization;

- cause of the organization;

- expansion of the knowledge;

- knowledge, concept;

- $\quad$ sign recording of the knowledge;

- meaning of the sign recording.

\begin{tabular}{|l|l|l|l|l|l|l|}
\hline Author & $\begin{array}{l}\text { Structure, } \\
\text { orderliness, } \\
\text { organization }\end{array}$ & $\begin{array}{l}\text { Cause of the } \\
\text { organization }\end{array}$ & $\begin{array}{l}\text { Expansion } \\
\text { of the } \\
\text { knowledge }\end{array}$ & $\begin{array}{l}\text { Knowledge, } \\
\text { concept }\end{array}$ & $\begin{array}{l}\text { Sign } \\
\text { recording } \\
\text { of the } \\
\text { knowledge }\end{array}$ & $\begin{array}{l}\text { Meaning } \\
\text { of the } \\
\text { sign } \\
\text { recording }\end{array}$ \\
\hline Bates & $\mathrm{x}$ & & & & & \\
\hline Bateson & & $\mathrm{x}$ & & & & \\
\hline $\begin{array}{l}\text { Belkin and } \\
\text { Robertson }\end{array}$ & & $\mathrm{x}$ & & & & \\
\hline Boauazza & & $\mathrm{x}$ & & & & \\
\hline Buckland & & & & & $\mathrm{x}$ & \\
\hline
\end{tabular}




\begin{tabular}{|c|c|c|c|c|c|c|}
\hline Author & $\begin{array}{l}\text { Structure, } \\
\text { orderliness, } \\
\text { organization }\end{array}$ & $\begin{array}{l}\text { Cause of the } \\
\text { organization }\end{array}$ & $\begin{array}{l}\text { Expansion } \\
\text { of the } \\
\text { knowledge }\end{array}$ & $\begin{array}{l}\text { Knowledge, } \\
\text { concept }\end{array}$ & $\begin{array}{l}\text { Sign } \\
\text { recording } \\
\text { of the } \\
\text { knowledge }\end{array}$ & $\begin{array}{l}\text { Meaning } \\
\text { of the } \\
\text { sign } \\
\text { recording }\end{array}$ \\
\hline Budd & & & & & $\mathrm{x}$ & \\
\hline Cornelius & & & & & $\mathrm{x}$ & \\
\hline Derr & & & & $\mathrm{x}$ & & \\
\hline Dretske & & & $\mathrm{x}$ & & & \\
\hline Fairthorne & & & & $\mathrm{x}$ & & \\
\hline Farradane & & & & & $\mathrm{x}$ & \\
\hline Floridi & & & & & $\mathrm{x}$ & \\
\hline Fox & & & & & & $\mathrm{x}$ \\
\hline Gackowski & & $\mathrm{x}$ & & & & \\
\hline Goguen & & & & & & $\mathrm{x}$ \\
\hline Hirshleifer & $\mathrm{x}$ & & & & & \\
\hline Krippendorff & & & & $\mathrm{x}$ & & \\
\hline Luhn & & $\mathrm{x}$ & & & & \\
\hline Losee & & & $\mathrm{x}$ & & & \\
\hline MacKay & & $\mathrm{x}$ & & & & \\
\hline Madden & & & $\mathrm{x}$ & & & \\
\hline Meadows & & & & & $\mathrm{x}$ & \\
\hline Nauta & & & & & & $\mathrm{x}$ \\
\hline Pratt & & & $\mathrm{x}$ & & & \\
\hline Resnikoff & & & & $\mathrm{x}$ & & \\
\hline Rogers & & & & & $\mathrm{x}$ & \\
\hline Stonier & $\mathrm{x}$ & & & & & \\
\hline Thompson & & & & $\mathrm{x}$ & & \\
\hline $\begin{array}{l}\text { Wersing and } \\
\text { Neveling }\end{array}$ & & $\mathrm{x}$ & & & & \\
\hline Wiener & & $\mathrm{x}$ & & & & \\
\hline
\end{tabular}

Table 2. Content categories

Subsequently, we attempted to establish what the concepts are in view of scope and to find such notions whose content and scope resemble the given concepts. The results can be conveniently defined within the two points below.

1) the concept of information somehow addresses the entire reality;

2) the concept of information is very close to some concepts used in philosophy - this fact is noted by Jonathan Furner [34], who claims, that the concept of information is in information science unnecessary, because all its meanings can be substituted by the concepts used in philosophy of the language -, or to the multidisciplinary terms, which relate to the whole lot of scientific disciplines.

First: We can note, that the information is defined as either 1) a structure, order, organization of something, 2) or eventually as a reason for this organization, or as something which a) broadens the knowledge about something, b) is a sign recording of this knowledge c) is the meaning of this sign recording. The universality of this concept is obvious: all that exists has some kind of a structure or organization, and we 
can have a knowledge about everything that is or can be (this postulate will be explained further). The universal character of the concept of information is obvious from the choice of the proximate genus in the listed definitions. A completely general genus (expressed by the words "what" or "that") is used, and the real determination is contained only in a specific difference. In all other cases, there are concepts which describe very general subjects and which can hardly be considered to be special concepts related to the specific discipline (pattern, difference, quality, artefact, representation, attribute, surrogate, data, factor, interpretation, value, message, stimulus, alternation, capacity, product, content).

Second: different definitions resemble a line of concepts related to ontology, epistemology, semantics, and other disciplines, which have universal or multidisciplinary character. Bateson's concept "difference that makes difference" points to the basic categories of the metaphysics, which asks what is identity and difference [15]. "Pattern of organization of matter and energy" by M. Bates, Stonier's "capacity to organize" or Hirshleifer's "negative measure of uncerntainty" are very close to what the Aristotelian philosophy calls a form [50]. MacKay's concept "that which determines form", Luhn's “structure-(form-)enriching message”, Gackowski's "factor in form", Wiener's "content of what is exchanged with the outer world", Belkin's and Robertson's "that which is capable of transforming structure", Boauazza's "that which reduces uncerntainty", Wersing's and Neveling's "reduction of uncerntainty caused by communicated data" resemble Aristoteles' concept of formal cause (i.e. the cause responsible for the form, shape of the things) [49, p. 91]. Dretsky's "what is capable of yielding knowledge", Madden's "stimulus which expands or amends the World View", Pratt's "alternation of the Image" appear to be related with the spiritual change (immutation) concept, used by Thomas Aquinas and who writes:

Now, immutation is of two kinds, one natural, the other spiritual. Natural immutation takes place by the form of the immuter being received according to its natural existence, into the thing immuted, as heat is received into the thing heated. Whereas spiritual immutation takes place by the form of the immuter being received, according to a spiritual mode of existence, into the thing immuted, as the form of color is received into the pupil which does not thereby become colored. Now, for the operation of the senses, a spiritual immutation is required, whereby an intention of the sensible form is effected in the sensile organ. [68, p. 393]

Derr's “abstract, meaningful representation", Thompson's "product that results from applying the processes of organization to the raw material of experience", Losee's "values in the characteristics of the processes' output", Resnikoff's "what remains after one abstracts from the material aspects of physical reality", Faithorney's "attribute of the receiver's knowledge and interpretation of the signal", Krippendorff's "measure of the (intellectual) work required to distinguish, to a degree better then chance, among a set of initially uncertain possibilities" have close to what is in 
epistemology and logic called a knowledge or a concept [54, p. 38]. Goguen's "interpretation of a configuration of signs", Bar-Hillel's "what is expressed by the signal sequence", Nauta's "that which is common to all representations that are synonymous to the interpreter" resemble the the concept of meaning [62], used by many disciplines (we can also put the Cornelius' definition in this category, according to which the information is a "human artefact constructed and reconstructed within social situations", if Cornelius understands the artefact as something immaterial - it is not quite obvious). Finally Farradan's "physical surrogate of knowledge", Buckland's "quality attributed to things", Floridi's "well-formed, meaningful and truthful data" and Meadows' "data processed and assembled into a meaningful form" are concepts related to the concept of document [10], which is used in librarianship, archival, museum science and other fields (if the Cornelius' artefact is some immaterial thing, then we can place his definition into this category). We can transparently show it in the following table:

\begin{tabular}{|c|c|c|c|}
\hline Concept & $\sim$ & Concept & Authors \\
\hline \multirow{5}{*}{ Information } & $\sim$ & Difference & Bateson \\
\cline { 3 - 4 } & Form & Bates, Stonier, Hirshleifer \\
\cline { 3 - 4 } & Formal cause & $\begin{array}{c}\text { Gackowski, MacKay, Luhn, Wiener } \\
\text { change }\end{array}$ & Dretske, Madden, Pratt \\
\cline { 3 - 4 } & & Concept & $\begin{array}{c}\text { Derr, Faithorne, Losee, Resnikoff, } \\
\text { Thompson }\end{array}$ \\
\cline { 3 - 4 } & Meaning & Bar-Hillel, Goguen, Nauta (Cornelius) \\
\cline { 2 - 4 } & Document & Buckland, Farradane, Meadows (Cornelius) \\
\hline
\end{tabular}

Table 2. Information and related concepts

What are the consequences for the concept of information in terms of its range? If the information is a structure or organization, then it must be included in all that is or may be (at least in the material world), because we can hardly imagine a thing that wouldn't be structured and organized. The total lack of order is nothing existing.

If the information is the knowledge about something, recording of that knowledge, or meaning of the recording, it is clear that we can have information about everything that is or can be. To admit the existence of reality, which we cannot have any knowledge about means having a knowledge about this reality (at least about its potential existence) (compare with [33, p. 16]. At that moment, however, such a postulate negates itself.

If we consider philosophy to be a universal science [1, p. 35], which is interested in the whole of reality, then the result of the philosophical investigation is information on everything that is. If every part of the reality (at least the material) is the subject of a special science, then a summary of information from particular disciplines will contact at least all that is, and that has material character. 
From this perspective, the concept of information seems to be a transcendental term, whether it is understood in ontological or epistemological sense. By different ways, Michael Buckland, comes to a similar conclusion, when he writes:

If anything is, or might be, informative, then everything is, or might well be, information. In which case calling something "information" does little or nothing to define it. If everything is information, then being information is nothing special. [11, p. 356]

\section{The concept and the future of information science}

Michal Lorenz [72] lists 7 problem areas of information science, of which two are relevant for our analysis:

1) the problem of delimitation,

2) the problem of the phenomenon under investigation.

Information science can be defined classically, as described above when we dealt with the definition of information, or pragmatically through the problems it addresses. Because we are inclined towards classic understanding of concepts and definitions, the crucial question for us is whether we can define information science as an autonomous discipline. By way of exemplification, let us have a look at a few definitions of information science. One of the most well-known and long-serving definitions is Harold Bork's definition:

Information science is that discipline that investigates the properties and behavior of information, the forces governing the flow of information, and the means of processing information for optimum accessibility and usability. It is concerned with that body of knowledge relating to the origination, collection, organization, storage, retrieval, interpretation, transmission, transformation and utilization of information. [73, p. 3]

In International Encyclopedia of Information and Library Science, R. T. Bottle defines information science as:

A discipline that investigates the characteristics of information and the nature of the information transfer process, whilst not losing sight of the practical aspects of collecting, collating and evaluating information and organizing its dissemination through appropriate intellectual apparatus and technology. [74, p. 295]

The last of the selected definitions was proposed by Chaim Zins: 
Information science is focused on the meta-knowledge aspect of objective knowledge, particularly on its technological and mediatory aspects. It expolores the phenomena, objects, and conditions that facilitate the accessibility to knowledge. [75]

According to Luciano Floridi [76], a field is autonomous if it meets the following conditions:

1) the field examines a unique topic and represents an autonomous field of research,

2) the field approaches its topics in a new, novel way that is reflected in its own, unique methodology,

3) the field is so stabilized that it is able to withstand all attempts to reduce the field of its interests to another field, thus demonstrating its adequate significance,

4) the field is broad and rich enough, so it can be organized into sub-fields in which specialists can specialize.

Conditions 2 and 4 are met. Information science has its own methods, including in particular bibliometry. The field also allows for a variety of specializations, such as information policy or information retrieval, as Lorenz points out [72]. The problem is with condition 1. Although most authors agree that the unique phenomenon that information science explores is information, there is no consensus on what information actually is, and there are some authors who identify as fundamental concept of information science another concept (knowledge, document). As regards the 3rd condition, information science is threatened by informatics (research of information systems and information retrieval), psychology and cognitive science (representation and organization of knowledge), management (information and knowledge management), pedagogy (information education, e-learning systems) or sociology (information society).

Our finding about the concept of information may shed light on the nature of the anomaly in information science which consists in the fact the information scientists are unable to agree (even within specific paradigms) on the definition of the concept that they consider to be the key one and in the problem that the autonomy of information science is constantly called into question. The concept of information is multidisciplinary, said in the words of the traditional logic, transcendental term. Information science defines itself as a special discipline (special sciences deal with a certain segment of reality and their concepts relate to this part; universal sciences such as philosophy are, on the other hand, interested in the whole of reality), namely one of the social sciences [20]. It appears that information science is a scientific discipline that works with transcendental term. We dare to consider such a situation to be a serious methodological problem.

Regardless to whether the information scientists themselves recognize this fact or not, there are attempts within information science to solve the problems with the concept of information, which - as it seems - respond to the problem associated with 
the scope of the term. They can be divided into three categories. In various works from the field of information science, we can hear, that it is necessary

1) for information science to undergo a transformation; the main concept defines the nature of the science; if the information is a universal concept, then information science must be a universal science too - creation of so called social epistemology, which aspires to become a general methodological solution for information science [31] can be considered to be such an attempt;

2) for the concept of information to undergo a transformation; if information science is a special science, it cannot work with a universal concept, so it is necessary to narrow the concept of information to the needs of this discipline (see [64, pp. 66-70];

3) for the concept of information to be replaced by another concept, which would clearly define the nature and borders of this discipline [32].

First: in information science, there is a long-time tension between the theoretical frame, which is tied to the concept of information and the specific sub-disciplines, which have constituted themselves because of the needs of praxis (typical example is the librarianship) and which did not use the concept of information and de facto still have not been using it (librarians keep talking about mediating information, but what they do, is still rather working with documents - documentation). Birger Hjørland and Rafael Capurro [13, p. 379] think, that behind the substitution of the concept of document by the concept of information, which led to the fact that the documentation had developed itself to information science, is the attempt to adapt to the new disciplines, such as computer science, where the concept of information is used. In these disciplines is the concept of information defined by a narrow technical way, which is not suitable for the discipline which generally deals with mediating information. Therefore, information science had to define the concept of information broader, and as it can be seen, the concept is too broad. This led some scientists to start associating information science with the cognitive science (so called cognitive turn), and also with epistemology, philosophy of science and sociology of knowledge [38]. This leads to two problems. The first one rests in the fact, that information science is moving away from its traditional sub-disciplines, like for example the librarianship. The second problem is, that it is not clear whether information science, when it associates with other disciplines, manages to keep its identity, or if it would dissolve in these disciplines as their sub-discipline. Beside it, there are attempts to create the most general science about information - philosophy of information [29], or a multidisciplinary discipline, which deals with the concept of information from the position of various disciplines (so called unified theory of information) [40], [41]. The entire process is logical, because the science has the same nature as its concepts; if the concept of information is transcendental, ontological and epistemological, information science must be also such discipline - so it should transform itself into philosophy of information. If it doesn't want to do so, (and it probably doesn't want, because it would mean even greater separation from the traditional disciplines, from 
which it originated), it is forced to do something with its fundamental concept. But that leads us to the next two points.

Second: there are attempts to narrow the general concept of information for the purpose of information science. M. Bates [3], who defines information as a "pattern of organization of matter and energy"; further classifies this broad concept according to various criteria and she finds, that the concept of information, which is in the centre of information science is always closest to what we call "exosomatic recorded information", i.e. information in the form of signs recorded on a tangible carrier. Michael Buckland [11] thinks that the subject of information science is "information as thing", i.e. an item which can be informative (book, museum exhibit etc.) Peter Ingwersen [42] and Jiř́ Cejpek [19] think similarly. They introduce the concept of "potential information." By the "potential information" they mean the sign recording, which can grow into the knowledge, if it meets a human mind.

There are two problems associated with these attempts. The first problem rests in the fact, that narrowing the concept of information will not relieve us from having the concept of information - we can narrow only what we have in a broad form. But as we have seen, information science doesn't have a general concept of information in a widely acceptable form (not even within the narrow frame of each paradigms). The second problem is, that the concept of information in its narrowed sense, as it is understood by Bates, Buckland, Ingwersen and Cejpek, is actually identical with the concept of document, associated with the traditional documentation [10]. So there is a question, why not to return to the original "document" notion. And so we get to the point three.

Third: within information science, there are attempts to leave the concept of information and to return back to the concept of document [32]. This solution, even though it is against the mind of the majority of the information scientists, because it means the necessity to admit, that introducing the concept of information was a dead end, looks quite optimistic on the first glance. However, there are some serious objections against it, which we can formulate as follows:

a. information science loses its identity as a science and it will be basically turned into the technique for working with documents (it will acknowledge that the attempt to elevate the practical field to the field of science failed);

b. entire fields will drop out of information science, for example research of information behaviour cannot be reduced to research of "behaviour when searching for documents" - it's much more complex field (the question is whether the information behaviour doesn't belong more into the psychology and sociology);

c. in the library practice, we cannot describe all types of services as documentary - when the librarian finds a certain fact, and he verbally passes it to the user, it is not a mediation of a document, if the document is not understood so widely, so that we consider an oral communication as a document too (one of the characteristics of the document, however, is its permanence, so a spoken word does not fit into the category of classically understood document). 
We can see that there are significant problems associated not only with the concept of information, but also with attempts to address these problems.

\section{Proposed perspectives}

Despite the above-indicated conditions, we assume that the most viable solution rests in combining together approaches 1 and 2 . In this context, the following steps appear to be inevitable:

1) accepting certain universality of information science;

2) finding a concept of information that will identify information science as a full-value discipline.

Such an approach means that the term of information is to be defined as a transcendental notion, categorizing information science as a transdisciplinary metafield (this procedure nevertheless requires information science to significantly exploit and rely on universal science, namely, philosophy and its subdisciplines, epistemology in particular; yet we can prospectively find such characteristics of the concept of information that will firmly establish information science within the broad set of disciplines.

\section{Conclusion}

The aim of our article was to analyze the concept of information, which is an anomaly in information science, from the epistemological and logical positions. Therefore, we were briefly acquainted with sorting the concepts in terms of scope. Then, we have analyzed 31 definitions of information and have concluded that the information is likely a concept that somehow contacts all reality, so that it is a concept which the classical logic would call a transcendental concept. This fact we, bearing in mind that information science is a special field, identified as a serious methodological problem, which has three possible solutions: transformation of information science into the universal science, narrowing the concept of information to a special concept and replacement of the concept of information by another one.

Each solution has its drawbacks. In the first case, it is clear that the established field may be very difficult to transform into another one. The second option does not solve the problem with the concept of information, whose general meaning is still in the game. Moreover, it appears that attempts to limit the concept of information leads to copying what is meant by the "document", and therefore to the return to traditional documentation. The third solution calls for the introduction of a new concept, to which the concept of document aspires (it is therefore a concept rather old-new). However, there are many problems associated with information science identity, with its scope and praxis.

It was not our purpose to resolve issues associated with the use of the concept of information in information science (the solution proposed by us is just a hint), but rather to point out the causes of this anomaly, contribute to the epistemological and 
logical debate over the nature of this concept and outline possible directions which information science could take in addressing these issues. We believe that the explanation of the problem with the concept of information, which lies in the fact, that the universal concept is used in a particular discipline, is properly justified and that it brings more light into the nature of the problem. We are leaving the question of how to address the given problems to further professional debate.

\section{References}

[1] Anzenbacher, A., Úvod do filosofie, SPN, Praha 1991.

[2] Bar-Hillel, Y., "An examination of information theory", Philosophy of Science, 1955, Vol. 22 No. 2, pp. 85-105.

[3] Bates, M.J., "Fundamental forms of information", Journal of the American Society for Information Science and Technology, 2006, Vol. 57 No. 8, pp. 1033-1045.

[4] Bates, M. J., "Information", in Encyclopedia of library and information sciences. CRC Press, New York 2010, pp. 2347-2360.

[5] Bateson, G., Steps to an ecology of mind, Ballantine Books, New York, NY 1972.

[6] Belkin, N. J. \& Robertson, S. E., "Information science and the phenomenon of information", Journal of. American Society of Information Science, Vol. 27, pp. 197-204.

[7] Belkin, N.J., "The cognitive viewpoint in information science", Journal of Information Science, 1990, Vol. 16 No. 1, pp. 11-15.

[8] Bouazza, A., "Information user studies", in Encyclopedia of Library and Information Science, Volume 44, supplement 9, Taylor and Francis, London 1989, pp. 144-164.

[9] Boulding, K.E., The image: knowledge of life and society, University of Michigan Press, Ann Arbor, MI 1961.

[10] Briet, S., What Is documentation?: english translation of the classic french text, The Scarecrow Press, Lanham 2006.

[11] Buckland, M., "Information as thing", Journal of the American Society for Information Science, 1991, Vol. 42 No. 5, pp. 351-360.

[12] Budd, J.M. "Meaning, truth, and information: prolegomena to a theory", Journal of Documentation, 2011, Vol. 67 No. 1, pp.56-74.

[13] Capurro, R. \& Hjørland, B., "The concept of information”, Annual Review of Information Science and Technology, 2003, Vol. 37, pp. 343-411. 
[14] Capurro, R., Fleissner, P. \& Hofkirchner, W., "Is a unified theory of information feasible?", in Hofkirchner, W. (Ed.), The quest for a unified theory of information, Overseas Publ. Association, Amsterdam 1999, pp. 9-30.

[15] Cardal, R., Identita a diference: systematický kurz ontologie, Academia Bohemica, Praha 2011.

[16] Cardal, R., “K metodě metafyzického výzkumu - Díl I.”, Distance, 2007, Vol. 10 No. 2, available at: http://www.distance.cz/rocnik-2007/2-cislo/kmetode-metafyzickeho-vyzkumu---dil-i (accessed 19 February 2016).

[17] Cardal, R., "K metodě metafyzického výzkumu - Díl II”, Distance, 2007, Vol. 10 No. 3., available at: http://www.distance.cz/rocnik-2007/3-cislo/kmetode-metafyzickeho-vyzkumudil-ii (accessed 19 February 2016).

[18] Case, D.O., Looking for information: a survey on research on information seeking, needs, and behavior, Academic Press, London 2006.

[19] Cejpek, J., Informace, komunikace a myšlení: úvod do informační vědy, Karolinum, Praha 1998.

[20] Cibangu, S., "Information science as a social science", Information Research, 2010, Vol. 15 No. 3, paper 434, available at: http://InformationR.net/ir/15-3/paper434.html (accessed 19 February 2016).

[21] Cornelius, I., "Information and interpretation", in Integration in perspective, proceedings of CoLIS 2: Second International Conference on Conceptions of Library and Information Science, Pergamon-Elsevier Science, Oxford 1996, pp. 11-22.

[22] Cronin, B., "The sociological turn in information science", in Information science in transition, Facet Publishing, London 2009, pp. 109-127.

[23] Day, R.E., The modern invention of information, Southern Illinois University Press, Carbondale 2001.

[24] Derr, R., "The concept of information in ordinary discourse", Information Processing and Management, 1985, Vol. 21 No. 6, pp. 489-499.

[25] Dretske, F., Knowledge and the flow of information, MIT Press 1981.

[26] Fairthorne, R. "The theory of communication", Aslib Proceedings, 1954, Vol. 6 No. 4, pp. 255-267.

[27] Farradane, J. "The nature of information", Journal of Information Science, 1979, Vol. 1 No. 1, pp. 13-17.

[28] Floridi, L., "Semantic conceptions of information", 2011, available at: http://plato.stanford.edu/entries/information-semantic/ (accessed 19 February 2016). 
[29] Floridi, L., The philosophy of information, Oxford University Press, Oxford 2011.

[30] Fox, C.J., Information and misinformation: an investigation of the notions of information, misinformation, informing and misinforming, Greenwood Press: Westport, CT 1983.

[31] Froehlich, T. J., "The foundations of information science in social epistemology", in System Sciences, 1989. Vol. IV: Emerging Technologies and Applications Track, Proceedings of the Twenty-Second Annual Hawaii International Conference on (Volume:4 ,) IEEE, 1989, pp. 306-314.

[32] Frohmann, B., Deflating information, University of Toronto Press, Toronto 2004.

[33] Fuchs, J., Filosofie. 3, Návrat k esenci, Krystal OP, Praha 2004.

[34] Furner, J., "Information studies without information", Library Trends, 2004, Vol. 52 No. 3, pp. 427-446.

[35] Gackowski, Z., "Subjectivity dispelled: physical views of information and informing”, Informing science, 2010, Vol. 13, pp. 165-175.

[36] Goguen, J., "Towards a social, ethical theory of information", in Bowker et al. (Eds.), Social science research, technical systems, and cooperative work, Lawrence Erlbaum Associates, Mahvah 1997, pp. 27-56.

[37] Hirshlefer, J., "Economics of information: where are we in the theory of information?", AER, Vol. 63 No. 2, pp. 31-39.

[38] Hjørland, B. \& Albrechtsen, H., "Toward a new horizon in information science: domain-analysis", Journal of the American Society for Information Science, 1995, Vol. 46 No 6, pp. 400-425.

[39] Hjørland, B., "Concept theory", Journal of the American Society for Information Science and Technology, 2009, Vol. 60 No. 8, pp. 1519-1536.

[40] Hofkirchner, W. (Ed.), The quest for a unified theory of information: proceedings of the Second International Conference on the Foundations of Information Science, Overseas Publ. Association, Amsterdam 1999.

[41] Hofkirchner, W., Emergent information: a unified theory of information framework. World Scientific, Singapore 2013.

[42] Ingwersen, P., "Cognitive perspective of information retrieval interaction", Journal of Documentation, 1996, Vol. 52 No 1, pp. 3-50.

[43] Kavouras, M. \& Kokla, M., Theories of geographic concepts: ontological approaches to semantic integration, CRC Press, Boca Raton 2007.

[44] Krippendorff, K., "Paradox and Information. Chapter 2", in Dervin, B. \& Voigt, M.J. (Eds.), Progress in Communication Sciences, 1984, Vol. 5, pp. 45-71. 
[45] Losee, R., "A discipline independent definition of information", Journal of the American Society for Information Science, 1997, Vol. 48 No. 3, pp. 254-269.

[46] Luhn, G., "The causal-compositional concept of information. Part I.", Information, 2012, Vol. 3 No. 1, pp. 151-174.

[47] MacKay, D., Information, mechanism, and meaning, MIT Press, Cambridge, MA 1969.

[48] Madden, A.D. "Evolution and information", Journal of Documentation, 2004, Vol. 60 No. 1, pp. 9-23.

[49] Machula, T., Filosofie přirody, Krystal OP, Praha 2007.

[50] Machula, T., Problémy hylemorfismu, Studia Neoaristotelica, 2005, Vol. 2 No. 1, pp. 26-38.

[51] Materna, P. \& Petrželka, J., Definition and concept: Aristotelian definition vindicated, Studia Neoaristotelica, Vol. 5 No. 1, pp. 3-37.

[52] Meadows, A.J. et al., Dictionary of computing and new information technology. Kegan Paul, 1984.

[53] Nauta, D., The meaning of information, Mouton, The Hague 1972.

[54] Novák, L. \& Dvořák, P., Úvod do logiky aristotelské tradice, Teologická fakulta Jihočeské univerzity v Českých Budějovicích, České Budějovice 2007.

[55] Ochrana, F., Metodologie vědy: úvod do problému, Karolinum, Praha 2009.

[56] Pratt, A., "The information of the Image: a model of the communications process", Libri, 1977, Vol. 27 No. 3, pp. 204-220.

[57] Prigogine, I. \& Stengers, I., Order out of chaos, Bantam, New York, NY 1984.

[58] Resnikoff, H., The illusion of reality, Springer-Verlag, New York 1989.

[59] Rogers, E.M., Communication technology, The Free Press, New York 1986.

[60] Skácel, M. \& Skácel, J., Základy vědecké filosofie, Cyrilo-Metodějské knihkupectví Gustava Francla, Praha 1945.

[61] Sousedík, S., Identitní teorie predikace, Oikoymenh, Praha 2006.

[62] Speaks, J., "Theories of meaning", 2011, available at:

http://plato.stanford.edu/archives/sum2011/entries/meaning/ (accessed 19 February 2016). 
[63] Stock, W.G., "Concepts and semantic relations in information science", Journal of the American Society for Information Science and Technology, 2010, Vol. 6 No. 10, pp. 1951-1969.

[64] Stodola, J., Informace, komunikace a bytí: fragment realistické informační vědy, J. Stodola, Brno 2010.

[65] Stonier, T., Information and the internal structure of the universe: an exploration into information physics, Springer-Verlag, London 1990.

[66] Šmajs, J., Drama evoluce: fragment evoluční ontologie, Hynek, Praha 2000.

[67] Thomson, F., "The organization is the information", American Documentation, 1968, Vol. 19 No. 3, pp. 305-308.

[68] Thomas Aquinas, Summa theologica. Volume 1. Part 1., Cosimo, New York, NY 2007.

[69] Wersig, G. \& Neveling, U., "The phenomena of interest to information science", The Information Scientist, 1975, Vol. 9 No. 4, pp. 127-140.

[70] Wiener, N., Cybernetics or control and communication in the animal and the machine, MIT Press, Cambridge, Mass. 1961.

[71] Wilson, T.D. "Information and information science", Information Research, 2010, Vol. 15 No. 4, paper 439, available at: 014 http://InformationR.net/ir/15-4/paper539.html (accesesed 2 February 2018).

[72] Lorenz, M. Hledání identity: historie a budoucnost informačních věd, Masarykova univerzita, Brno 2018 (in print).

[73] Borko, H. "Information Science: What Is It?", American Documentation. 1968, Vol. 19 No. 1., pp. 3-5.

[74] Feather, J. \& Sturges, P. (Eds.), International encyclopedia of information and library science, Routlegde, London 2003.

[75] Zins, Ch. "Redefining information science: from information science to knowledge science”, Journal of Documentation, 2006, Vol. 62 No. 4, pp. 447-461.

[76] Floridi, L., "On defining library and information science as applied philosophy of information”, Social Epistemology, 2002, Vol. 16 No. 1, pp. 37-49. 